\title{
DRUG EFFECTS ON AQUACULTURE AND IT'S REMEDIATION
}

\author{
Soumik Banerjee ${ }^{1}$, *Dr. Vikram Kumar ${ }^{2}$, Prof. (Dr.) A.N. Pathak ${ }^{3}$ \\ ${ }^{1}$ Biotechnology Scholar, Amity Institute of Biotechnology; Amity University Rajasthan, Jaipur, India- 303007 \\ ${ }^{2}$ Senior Lecturer, Pharmacology, Amity Institute of Biotechnology; Amity University Rajasthan, Jaipur, India- 303007 \\ ${ }^{3}$ Director, Amity Institute of Biotechnology; Amity University Rajasthan, Jaipur, India- 303007 \\ *Corresponding Author's E-mail: vikramyadav05@gmail.com, Mobile No. +91-9887755545
}

\begin{abstract}
Aquaculture plays an important role in global food production. Due to changes in human dietary habits, fish consumption has been increasing, with more people changing to a healthier diet with an appropriate nutritional profile. Aquaculture has become an important source of fish available for human consumption. In order to achieve greater productivity, intensive fish cultivation systems are employed, which can cause greater susceptibility to diseases caused by viruses, bacteria, fungi, and parasites. Antimicrobial substances are compounds used in livestock production with the objectives of inhibiting the growth of microorganisms and treatment or prevention of diseases. It is well recognized that the issues of antimicrobial use in food animals are of global concern about its impact on food safety. In this paper we will review the effects of various drugs that are used in this specific industry on human health as well as animal health. Although the production of many lower trophic level aquaculture species might be desirable, the wisdom of farming carnivorous fish on a large scale has been called into question.
\end{abstract}

Keyword: Aquaculture, fish cultivation, food safety

\section{INTRODUCTION}

Industrial aquaculture is a rapidly growing industry in many developed and developing countries. ${ }^{1}$ The last 20 years have seen a fourfold growth in industrial aquaculture worldwide ${ }^{2-3}$

Global consumption of fish has doubled since the early 1970s and will continue to grow with population, income, and urban growth in the developing world. ${ }^{4}$ The demand of fish in industrialized countries is also increasing but the demand differs according to taste and wealth. Like common carp and mollusks are generally preferred by the consumers who dwell in the developing countries whereas the wealthy consumers prefer fishes like shrimp and carnivorous fin-fish species such as salmon, cod, halibut, and tuna. ${ }^{3}$ Aquaculture production of marine carnivorous finfish has grown by roughly $10 \%$ annually, and its value has increased by about $5 \%$ per annum since the early 1990s ${ }^{5}$. This impressive industrial development has indeed been accompanied with some drug application practices that is affecting the human and animal health. The drugs include various veterinary drugs ${ }^{6}$ and also prophylactic antibiotics ${ }^{1}$. How this practice is going to affect the human and animal health? Will this practice of heavy use of various drugs will result in the net gain, or net drain of the global aquaculture market? This process of aquaculture is not only driven by the rising global demand of fishes but also due to lucrative business opportunities. Although the production of many lower trophic level aquaculture species might be desirable, the wisdom of farming carnivorous fish on a large scale has been called into question. Work on salmon aquaculture, in particular, has shown that farming such fish can have negative environmental and social implications for areas and parties vastly separated in space ${ }^{7-10}$.

\section{The need of aquaculture:}

It is long seen that the oceans are a potential, vast, inexhaustible source of marine organisms especially fishes. Although the fresh water and fisheries farming of fishes began to deplete, many people had the thought of oceans as the never ending source of fishes. Thus fishery technology and management policies had been adjusted accordingly, allowing the management baseline of fish capture in the oceans and capturing a vast range of fishes. $^{4,11-13}$ Over $60 \%$ of the marine fish stocks for which information is available are either fully exploited or overexploited, and 13 of the world's 15 major oceanic fishing areas are now fished at or beyond capacity. ${ }^{14}$ Small fish at the low end of the food chain compose an increasing share of global catch ${ }^{15}$, whereas populations of commercially valuable, large predatory fish-the type many human consumers prefer-continue to decline. By one estimate, commercial fishing has wiped out $90 \%$ of large fish such as swordfish, cod, marlin, and sharks ${ }^{16}$. In addition to impacts caused by the fishing activities, the marine ecosystems and the fisheries face a major problem from the other sources such as climate change, run offs in land-based pollutants, introductions and invasion of exotic species, costal development and habitat alteration, and especially uses of various drugs in aquaculture. $11,17,18$

Roughly $40 \%$ of all fish directly consumed by humans worldwide are now farmed. Although most aquaculture production to date has been of freshwater fish, marine aquaculture has been growing dramatically. Global production of farmed salmon, for example, has roughly quadrupled in volume since the early 1990s. This spectacular increase and the resulting decline in salmon prices have helped prompt aquaculturists to begin 
farming numerous other marine finfish, including a number of species depleted in the wild. New species farmed in marine net pens include Atlantic cod (Gadus morhua), Atlantic halibut (Hippoglossus hippoglossus), Pacific thread fin (Polydactylus sexAl)i,smutton snapper (Lutjanus analis), and bluefin tuna (Thunnus spp.). ${ }^{2}$ Like salmon, many of these new species are farmed in net pens or cages that are anchored to the ocean bottom, often in coastal waters 9. Marine aquaculture development is being promoted in many countries, and parts of the industry are now emerging as major competitors in international markets ${ }^{8,}{ }^{19}$. It has responded to the rising role of large retail chains by supplying homogeneous, made-to-order products on a year-round basis. It has also developed computerized information flows on fish stocks and markets, web-based business to business interactions, and in some cases, supply chains that control fish production from hatcheries to sales. The industry has benefited from rapid expansion of seafood trade and overnight transportation of fresh products around the world. In many cases, the aquaculture industry has been able to out compete the capture fishing industry, partly because subsidies and other policies supporting the fishing industry have impeded adjustments to make it more efficient ${ }^{19}$. Given these trends and the limited capacity of oceans to provide more fish for human consumption, it is likely that aquaculture will dominate fish production in the coming decades and thus the need of aquaculture is very much evident.

\section{Scenario in Asia-Pacific:}

The aquaculture industry in Asia is growing rapidly, with the development of methods and markets for new species. Asia, particularly China, contributes significantly to global aquaculture production. More than $90 \%$ of the world's aquaculture production is coming from Asia. Further, the majority of aquaculture production of fish, crustaceans and mollusks continues to come from the freshwater environment $(57.7 \%$ by volume and $48.4 \%$ by value). ${ }^{20}$ Like other farming sectors, the aquaculture industry must also deal with diseases caused by varieties of pathogens.

The increasing popularity of aquaculture has made it possible for the aquatic viruses to be more and more spread. The endemic viral diseases has made the very constrain for efficient aquaculture production and thus has detrimental effects on the aquaculture industry worldwide. $^{21}$

Various viral diseases have been reported that affects the aquaculture industry in the Asia-Pacific region. These are Spring veremia of Carp, Infectious hematopoetic necrosis, Epizootic hematopoetic necrosis, Viral haemorrhagic septicaemia, Infectious pantreatic necrosis, Koi herpes virus, Infectious spleen and kidney necrosis, Viral encephalopathy and retinopathy, Viral nervous necrosis, Lymphocystis disease, Carp pox, Herpes viral hematopoetic necrosis of Goldfish and Chinese grass carp reovirus disease. ${ }^{21}$ Many of the antiviral vaccines are commercially available and many are not, which are still under valuable research.

Present situation of Biocide use in Aquaculture:
With the rapid expansion of the aquaculture industry and with constricting legislation of the use of antifouling (AF) biocides, the problem of aquaculture biofouling has increased greatly ${ }^{22-25}$. The herbicides or fungicides currently used in aquaculture were originally developed for use in agriculture or as additives for boat anti-fouling paints ${ }^{26}$. Accordingly, many studies have investigated and demonstrated the presence of pesticides and biocides in surface waters ${ }^{27-31}$.

As the triorganotin based formulations (e.g., tributyltin (TBT)), copper has become the principal biocidal component of most AF paints. It usually comes in the form of copper oxide $\left(\mathrm{Cu}_{2} \mathrm{O}\right){ }^{22}$. Inorganic zinc is often used in combination with copper to increase the overall toxicity of the formulation or to facilitate the leaching process. $^{32}$ Organic booster biocides, such as Irgarol $1051^{\circledR}$, Sea Nine $211^{\circledR}$, dichlofluanid, chlorothalonil, zinc pyrithione, and Zineb are also added to the paint to enhance its effectiveness ${ }^{33}$. Nevertheless, these alternatives to TBT are also toxic and their contamination of the aquatic environment has been a topic of increasing importance in recent years ${ }^{26}$. Many studies have shown that the toxicity of booster biocides on non-target species are growth inhibitors for freshwater and marine autotrophs ${ }^{34}$, influencing key species, such as sea grass ${ }^{35}$, and even corals ${ }^{36}$. Therefore, there is increasing interest in the impact of these compounds on the aquatic ecosystems ${ }^{37}$. As vertebrates that have immune systems strikingly similar to those of mammals, they can also be used to identify potential threats to terrestrial wildlife and humans ${ }^{38,39}$. The risk to predators and humans through the consumption of fish is very low, especially for humans, since the latter are less exposed to the dangers of contamination due to the fact that fish constitutes only a small part of their diet ${ }^{40}$. However, the risk may be elevated owing to the mechanism of resistance of the drugs.

\section{Present situation of Heavy use of Antibiotics in aquaculture:}

In aquaculture, especially that of salmon, nearly all the fishes raised undergoes manipulations are stressors ${ }^{41}$. Because these manipulations decrease the effectiveness of the fishes' immune system to clear up bacterial colonization and infection, it has become a common practice to introduce and use high doses of prophylactic antibiotics 2, 41-42. Once in the environment, these antibiotics can be ingested by wild fish and other organisms including shellfish ${ }^{43-46}$. These residual antibiotics will remain in the sediment, exerting selective pressure, thereby altering the composition of the microflora of the sediment and selecting for antibioticresistant bacteria $43,47,48$. There are a number of important studies that indicate that the bacterial flora in the environment surrounding aquaculture sites contains an increased number of antibiotic-resistant bacteria and that these bacteria harbour new and previously uncharacterized resistance determinants $46,49-51$. The exchange of resistance determinants between the aquatic and terrestrial environment can also stem from the movement of antibiotic-resistant bacteria between these two environments, a result of transporting fish between bodies of freshwater and the ocean, a step that is needed to fulfill the developmental requirements of salmonids ${ }^{2 \text {, }}$ 
9, 42. Horizontal gene transfer mechanisms involved in exchanging resistance determinants between aquatic and terrestrial bacteria include conjugation and conjugative transposition 52-54. However, transduction also has the potential to play an important role in these processes because of the high concentrations of viruses in seawater and the marine sediment ${ }^{53}$. In many aquaculture settings in developing countries, the possibilities of these exchanges have been amplified by the high level of contamination of seawater and freshwater with untreated sewage and agricultural and industrial wastewater containing normal intestinal flora and pathogens of animals and humans usually resistant to antibiotics 42,46 , 51 . This is also the case in settings in which aquaculture is integrated with agriculture, and such practices such as the use of manure and other agricultural residues as fish feed are widespread ${ }^{55}$.

The presence of antibiotics in the aquatic environment can result in the appearance of resistance among human pathogens forming part of its micro-biota. For example, $V$. cholera of the Latin American epidemic of cholera that started in 1992 appeared to have acquired antibiotic resistance as a result of coming into contact with antibiotic-resistant bacteria selected through the heavy use of antibiotics in the Ecuadorian shrimp industry ${ }^{56}$.

Another problem created by the excessive use of antibiotics in industrial aquaculture is the presence of residual antibiotics in commercialized fish and shellfish products. This problem has led to undetected consumption of antibiotics by consumers of fish with the added potential alteration of their normal flora that increases their susceptibility to bacterial infections and also selects for antibiotic-resistant bacteria. Moreover, undetected consumption of antibiotics in food can generate problems of allergy and toxicity, which are difficult to diagnose because of a lack of previous information on antibiotic ingestion ${ }^{42,46,56-60}$.

This suggests that the unrestricted use of antibiotics in aquaculture in any country has the potential to affect human and animal health on a global scale, and further suggests that this problem should be dealt through unified local and global preventive approaches.

\section{Effects of disease outbreak prevention drugs in aquaculture:}

Several chemical compounds or drugs are utilized for the treatment of disease outbreak in aquaculture. These are commonly administered by two different routes: by prolonged immersion or by mixing into diet. In the case of intensive aquaculture, the chemicals that are most frequently applied by immersion are formaldehyde (FA) $37 \%$ and oxytetracycline (OTC). The first is highly effective against most protozoa, as well as some of the most common parasites such as monogenetic trematodes. OTC presents a large spectrum of antibacterial activities and is used to treat systemic bacterial infections that affect fish. The chemicals have been shown to have genotoxic and cytotoxic potential following a timedependent pattern ${ }^{61}$. Cytotoxic drugs are highly toxic to cells, mainly through their action on cell reproduction. Many have proved to be carcinogenic, mutagenic or teratogenic ${ }^{62}$. Remarkably, the combined treatment induces a cumulative effect, which suggests the critical (c) 2011, JDDT. All Rights Reserved hazards associated with exposure to FA and OTC when applied or released together ${ }^{61}$.

\section{Health effects use of drugs used in aquaculture on humans:}

The potential health effects from added chemicals are also a concern for consumers. Shipments of frozen salmon from Chile were found in Europe in 2003 with unsafe quantities of malachite green, a carcinogenic fungicide prohibited for salmon farm use in Chile since 1995 and widely prohibited around the world ${ }^{77}$. Japan also suspended imports of some Chilean salmon in 2003 owing to antibiotic loads higher than are permitted under Japan's health code ${ }^{77}$. The main worry with excessive antibiotic use in aquaculture is that over time it promotes the spread of resistance in both human and fish pathogens ${ }^{78}$. Antibiotic use is said to have declined on farms, especially in advanced regions such as Norway, but the full extent of antibiotic use in the industry is unclear ${ }^{77}$. Finally, consumer-related concerns over the use of colorants in salmon feeds to produce desired flesh tones are also widely debated ${ }^{80,81}$. The health effects of colorants are not thought to be too severe; the only proven side effects of moderate over dosage of the natural dye, canthaxanthin, by humans is reversible deposition of crystals in the eye ${ }^{79}$. Although the colorant issue will not likely arise in the production of most other farmed carnivorous finfish whose natural flesh colors in the wild are not bright like that of salmon, the contaminant issue is expected to remain controversial, particularly for the more fatty farmed fish.

\section{Remediation of adverse drug effects:}

The widespread and massive utilisation of antibacterial drugs in intensive farming poses the question of their environmental fate and side effects. The release of drugs into the environment is responsible for the contact of wild organisms with amounts of single (or a few) active pharmacological materials. While human wastes usually contain low amount of many different drugs, animal waste contains high amounts of usually one or few antibacterial drugs ${ }^{63}$.

Macrophyte-based treatment appears to be highly competitive among the existing refined treatment methods; the type of aquatic plant used can make a significant difference in the pollutant removal ${ }^{64-65}$. The water velvet is an aquatic fern known to absorb pollutants and to be quite resistant to antibiotics ${ }^{66-69}$. Duckweed is another freefloating aquatic plant known to absorb pollutants, and under study to evaluate its resistance to Flumequine ${ }^{70}$. The floating macrophyte water lettuce is another promising bioremediation candidate, known to absorb heavy metals ${ }^{71}$.

The fisheries and aquaculture industry can be revolutionized by using nanotechnology with new tools like rapid disease detection, enhancing the ability of fish to absorb drugs like hormones, vaccines and nutrients etc. rapidly. Disease outbreak is one of the major problems to deal with in the aquaculture and thus heavy use of vaccination is given to the raised fishes in aquaculture as we have seen before. The use of oil emulsion as adjuvant in this effort may cause major drawbacks as some fishes and shellfishes show 
unacceptable levels of side effects. These provide a detrimental effect on the aquaculture species. This can be overcome by the simple usage of nanotechnology in drug delivery. use of nanoparticle carriers like chitosan and poly-lactide-co-glycolide acid (PLGA) ${ }^{72}$ of vaccine antigens together with mild inflammatory inducers may give a high level of protection to fishes and shellfishes not only against bacterial diseases, but also from certain viral diseases with vaccine-induced side effect. Further, the mass vaccination of fish can be done using nanocapsules containing nano-particles. These will be resistant to digestion and degradation. These nanocapsules contain short strand DNA which when applied to water containing fishes are absorbed into fish cells. The ultrasound mechanism is used to break the capsules which in turn release the DNA thus eliciting an immune response to fish due to the vaccination. Similarly, oral administration of these vaccines and sitespecific release of the active agent for vaccination will reduce the cost and effort of disease management, application of drug and vaccine delivery etc., at the same cost of feeding leading to sustainable aquaculture ${ }^{73}$.

Managing and proper treatment of aquaculture effluent is essential to reduce or eliminate any offsite environmental impact. Aquaculture effluent commonly contains organic and inorganic dissolved, suspended and settleable solids as a result of feeding practices. Since the systems (recirculating systems, ponds, cages, raceways) and culture practices (feeds, feeding rates, water treatment), and physical features of the facility vary, several effluent treatment options and management practices are provided to allow for flexibility. The recommended remediation management techniques are Detention System, Integrated production system treatment, Vegetated filter strip treatment, Retention or Zero discharge treatment, Wetland treatment and other upcoming treatments ${ }^{74}$.

Water purifying microorganism does not have following disadvantages: poison, side effect, residue, secondary pollution, and resistance to drug. It can improve the ecological environment of aquatic water, maintain the aquatic ecological balance, strengthen the immunity of aquatic animal and reduce the emergence of the disease effectively, thus gaining more and more extensive application $^{75}$.

Hydrogen peroxide therapy also shows promise to control mortalities associated with external bacterial infections and to control parasitic infestations in cultured freshwater fish. Hydrogen peroxide is used outside the
United States for treatment of external fungal and bacterial infections or parasitic infestations in cultured fish, particularly for sea lice control in marine salmon net pens in Canada, Scotland, Ireland, Norway, and Chile. Hydrogen peroxide naturally degrades to water and oxygen by various mechanisms, including chemical reduction and enzymatic (catalase and peroxidase) decomposition by algae, zooplankton, and heterotrophic bacteria. Microorganisms, especially bacteria, account for the majority of degradation, significantly more than all other chemical and biological mechanisms. The rate at which $\mathrm{H}_{2} \mathrm{O}_{2}$ decomposes in natural water can vary from a few minutes to more than a week, depending on numerous chemical, biological, and physical factors. The rapid degradation rates are primarily the result of microbial action, whether $\mathrm{H} 202$ is at naturally occurring concentrations or at concentrations 1000 to 10,000 times higher (from anthropogenic inputs during in situ chemical or bioremediation of groundwater). In eutrophic to somewhat oligotrophic fresh water, halflives of 2 to $8 \mathrm{~h}$ are typical for $\mathrm{H}_{2} \mathrm{O}_{2}$ at naturally occurring levels, whereas the half-life may be several days or more in water devoid of microorganisms ${ }^{76}$.

\section{CONCLUSION:}

From the above evaluated studies of the uses, effects and their remediation it is very much evident that there is a huge perspective of research in the field of aquaculture drug resistance remediation. In this review we have seen the various uses of Biocides, Antibiotics use in aquaculture and tried to give a prospective on the treatment of these drug resistances by the various target organisms of the drugs.

The use of many drugs is not as well regulated as drug use in aquaculture and thus should be monitored accordingly while usage, because the effects, mainly adverse, are not as of late known to us and is still under valuable research. It is also important to evaluate the effects of these compounds through the continuous monitoring of concentration profiles in water, sediment and biota to provide information that could lead to concerted action to ban or regulate their use.

\section{ACKNOWLEDGEMENT:}

The author is very thankful with to Prof. (Dr.) A.N.Pathak Director Amity Institute of Biotechnology, Amity University Rajasthan, Jaipur for valuable guidance, suggestions and advice during the preparation of this manuscript. 


\section{REFERENCES}

1) Cabello, F. C. (2006), Heavy use of prophylactic antibiotics in aquaculture: a growing problem for human and animal health and for the environment. Environmental Microbiology, 8: 1137-1144. doi: 10.1111/j.1462-2920.2006.01054.x

2) Naylor, R., and Burke, M. (2005) Aquaculture and ocean resources: raising tigers of the sea. Annu Rev Environ Resources 30: 185-218.

3) Naylor, R.L., Goldburg, R.J., Primavera, J.H., Kautsky, N., Beveridge, M.C.M., Clay, J., et al. (2000) Effect of aquaculture on world fish supplies. Nature 405: 1017- 1024

4) Delgado C, Wada N, Rosegrant M, Meijer S, Ahmed M. 2003. Outlook for Fish to 2020: Meeting Global Demand. Washington, DC: Int. Food Policy Res. Inst.

5) FAO. 2009. FISHSTAT Plus. UN Food Agric. Organ., Fish. Dep., Fish. Inf., Data, Stat. Dep.

6) Haya, K., Burridge, L.E., and Chang, B.D. (2000) Environmental impact of chemical wastes produced by the salmon aquaculture industry. ICES J Mar Sci 58: 492-496.

7) Weber M. 2003. What Price Farmed Fish: A Review of the Environmental and Social Costs of Farming Carnivorous Fish. Washington, DC: SeaWeb Aquac. Clgh.

8) Naylor R, Eagle J, Smith W. 2003. Salmon aquaculture in the Pacific Northwest: a global industry with local impacts. Environment 45:18-39

9) Goldburg R, Naylor R. 2004. Future seascapes, fishing, and fish farming. Front. Ecol. 3:21-28

10) Morton A, Hume S, Keller B, Leslie R, Langer O, Staniford D. 2004. A Stain Upon the Sea: West Coast Salmon Farming. Madeira Park, BC: Harbour. 288 pp.

11) Hilborn R, Branch $T$, Ernst B, Magnusson A, Minte-Vera C, et al. 2003. State of theWorld's Fisheries. Annu. Rev. Environ. Resour. 28:359-99.

12) Pauly D, Alder J, Bennett E, Christensen V, Tyedmers P, Watson R. 2003. The future for fisheries. Science 302:135961

13) Pauly D, Christensen V, Guenette S, Pitcher T, Sumalia U, et al. 2002. Towards sustainability in world fisheries. Nature 418:689-95

14) FAO. 2002. State of the World's Fisheries and Aquaculture. Rome, Italy: UN Food Agric. Organ.

15) Pauly D, Christensen V, Dalsgaard J, Froese R, Torres FJ. 1998. Fishing down marine food webs. Science 279:860-63

16) Myers R, Worm B. 2003. Rapid worldwide depletion of predatory fish communities. Nature 423:280-83

17) Pew Oceans Comm. 2003. America's Living Oceans: Charting a Course for Sea Change. Washington, DC: Pew Oceans Comm.

18) USCOP. 2004. An Ocean Blueprint for the 21st Century. Washington, DC: US Comm. Ocean Policy

19) Eagle J, Naylor R, Smith W. 2004. Why farm salmon outcompete fishery salmon. Mar. Policy 28:259-70

20) Sahoo, P. K., and A. E. Goodwin. "Viruses of Freshwater Finfish in the Asian-Pacific Region." Indian Journal of Virology 23.2 (2012): 99-105.

21) Sahoo, P. K., and A. E. Goodwin. "Viruses of Freshwater Finfish in the Asian-Pacific Region." Indian Journal of Virology 23.2 (2012): 99-105.

22) Yebra D.M., Kiil S., Dam-Johansen K. Antifouling technology-past, present and future step towards efficient and environmentally friendly antifouling coatings. Prog. Org. Coat.2004;50:75-104.

23) Bazes A., Silkina A., Defer D., Bernède-Bauduin C., Quéméner E., Braud J.P., Bourgougnon N. Active substances fromCeramium botryocarpum used as antifouling products in aquaculture. Aquaculture.2006;258:664-674

24) Fusetani N. Biofouling and antifouling. Nat. Prod. Rep. 2004;21:94-104

25) Braithwaite R.A., McEvoy L.A. Marine biofouling on fish farms and its remediation. Adv. Mar. Biol. 2005;47:215-252

26) Konstantinou I.K., Albanis T.A. Worldwide occurrence and effects of antifouling paint booster biocides in the aquatic environment.Environ. Int. 2004;30:235-248
27) Hoffmann R.S., Capel D.C., Larson S.J. Comparison of pesticides in eight U.S. urban streams. Environ. Toxicol. Chem.2000;19:2249-2258

28) Blanchoud H., Moreau-Guigon E., Farrugia F., Chevreuil M., Mouchel J.M. Contribution by urban and agricultural pesticide uses to water contamination at the scale of the Marne watershed. Sci. Total Environ. 2007;375:168-179.

29) Singer H., Jaus S., Hanke I., Lück A., Hollender J., Alder A.C. Determination of biocides and pesticides by on-line solid phase extraction coupled with mass spectrometry and their behaviour in wastewater and surface water. Environ. Pollut.2010;158:3054-3064.

30) Wittmer I.K., Bader H.P., Scheidegger R., Singer H., Lück A., Hanke I., Carlsson C., Stamm C. Significance of urban and agricultural land use for biocide and pesticide dynamics in surface waters. Water Res. 2010;44:2850-2862.

31) Wittmer I.K., Scheidegger R., Bader H.P., Singer H., Stamm C. Loss rates of urban biocides can exceed those of agricultural pesticides. Sci. Total Environ. 2011;409:920932.

32) Watermann B.T., Daehne B., Sievers S., Dannenberg R., Overbeke J.C., Klijnstra J.W., Heemken O. Bioassays and selected chemical analysis of biocidefree antifouling coatings. Chemosphere. 2005;60:1530-1541.

33) Parks R., Donnier-Marechal M., Frickers P.E., Turner A., Readman J.W. Antifouling biocides in discarded marine paint particles.Mar. Pollut. Bull. 2010;60:1226-1230.

34) Okamura H., Nishida T., Ono Y., Shim W.J. Phytotoxic effects of antifouling compounds on nontarget plant species. Bull. Environ. Contam. Toxicol. 2003;71:881-886.

35) Chesworth J.C., Donkin M.E., Brown M.T. The interactive effects of the antifouling herbicides Irgarol 1051 and Diuron on the seagrass Zostera marina (L.) Aquat. Toxicol.2004;66:293-305

36) Owen R., Knap A., Toaspern M., Carbery K. Inhibition of coral photosynthesis by the antifoling herbicide Irgarol 1051. Mar. Pollut. Bull. 2002;44:623-632.

37) Sánchez-Rodríguez A., Sosa-Ferrera Z., Santana-del Pino A., Santana-Rodríguez J.J. Probabilistic risk assessment of common booster biocides in surface waters of the harbours of Gran Canaria (Spain) Mar. Pollut. Bull. 2011;62:985-991.

38) Anderson D.P., Zeeman M.G. Immunotoxicology in Fish. In: Rand G.M., editor. Fundamentals of Aquatic Toxicology: Effects, Environmental Fate, and Risk Assessment. 2nd ed. Taylor \& Francis; Washington, DC, USA: 1995. pp. 371-404.

39) Luebke R.W., Hodson P.V., Faisal M., Ross P.S., Grasman K.A., Zelikoff J. Aquatic pollution-induced immunotoxicity in wildlife species. Fundam. Appl. Toxicol. 1997;37:1-15.

40) Muñoz I., Martínez Bueno M.J., Agüera A., Fernández-Alba A.R. Environmental and human health risk assessment of organic micro-pollutants occurring in a Spanish marine fish farm. Environ. Pollut. 2010;158:1809-1816.

41) Barton, B.A., and Iwama, G.K. (1991) Physiological changes in fish from stress in aquaculture with emphasis on the response and effects of corticosteroids. Annu Rev Fish Dis1: $3-26$.

42) Cabello, F.C. (2003) Antibiotics and aquaculture. An analysis of their potential impact upon the environment, human and animal health in Chile. Fundacion Terram. Analisis de Politicas Publicas No. 17, pp. 1-16.

43) Hektoen, H., Berge, J.A., Hormazabal, V., and Yndestad, M.(1995) Persistence of antibacterial agents in marine sediments. Aquaculture 133: 175-184.

44) Kerry, J., Coyne, R., Gilroy, D., Hiney, M., and Smith, P. (1996) Spatial distribution of oxytetracycline and elevated frequencies of oxytetracycline resistance in sediments beneath a marine salmon farm following oxytetracycline therapy. Aquaculture 145: 31-39.

45) Coyne, R., Hiney, M., and Smith, P. (1997) Transient presence of oxytetracycline in blue mussels (Mytilus edulis) following its therapeutic use at a marine Atlantic salmon farm. Aquaculture 149: 175-181.

46) Sørum, H. (2006) Antimicrobial drug resistance in fish pathogens. In Antimicrobial Resistance in Bacteria of 
AnimalOrigin. Aarestrup, F.M. (ed.). Washington, DC, USA: American Society for Microbiology Press, pp. 213-238 (Chapter 13).

47) Kruse, H., and Sørum, H. (1994) Transfer of multiple drug resistance plasmids between bacteria of diverse origins in natural microenvironments. Appl Environ Microbiol 60: 4015-4021.

48) Davison, J. (1999) Genetic exchange between bacteria in the environment. Plasmid 42: 73-91.

49) Huys, G., Rhodes, G., McGann, P., Denys, R., Pickup, R., Hiney, M., et al. (2000) Characterization of oxytetracyclineresistant heterotrophic bacteria originating from hospital and freshwater fishfarm environments in England and Ireland. Syst Appl Microbiol 23: 599-606.

50) Schmidt, A.S., Bruun, M.S., Dalsgaard, I., and Larsen, J.L. (2001a) Incidence, distribution, and spread of tetracycline resistance determinants and integron-associated antibiotic resistance genes among motile aeromonads from a fish farming environment. Appl Environ Microbiol 67: 56755682.

51) Miranda, C.D., and Zemelman, R. (2002b) Antimicrobial multiresistance in bacteria isolated from freshwater Chilean salmon farms. Sci Total Environ 293: 207-218.

52) Agerso, Y., and Guardabassi, L. (2005) Identification of Tet 39 , a novel class of tetracycline resistance determinant in Acinetobacter spp. of environmental and clinical origin. $J$ Antimicrob Chemother 55: 566-569.

53) Bushman, F. (2002b) Phage transduction and bacterial pathogenesis. In Lateral DNA Transfer. Mechanisms and Consequences. Cold Spring Harbor, NY, USA: Cold Spring Harbor Laboratory Press, pp. 73-128.

54) Casas, C., Anderson, E.C., Ojo, K.K., Keith, I., Whelan, D., Rainnie, D., and Roberts, M.C. (2005) Characterization of pRAS1-like plasmids from atypical North American psychrophilic Aeromonas salmonicida. FEMS Microbiol Lett 242: 59-63.

55) Petersen, A., Andersen, J.S., Kaewmak, T., Somsiri, T., and Dalsgaard, A. (2002) Impact of integrated fish farming on antimicrobial resistance in a pond environment. Appl Environ Microbiol 68: 6036-6042.

56) Angulo, F.J. (2000) Antimicrobial agents in aquaculture: potential impact on health. APUA Newsletter 18: 1-6.

57) Grave, K., Markestad, A., and Bangen, M. (1996) Comparison in prescribing patterns of antibacterial drugs in salmonid farming in Norway during the periods 1980-1988 and 1989-1994. J Vet Pharmacol Therap 19: 184-191.

58) Alderman, D.J., and Hastings, T.S. (1998) Antibiotic use in aquaculture: development of antibiotic resistance - potential for consumer health risks. Int J Food Sci Technol 33:139155.

59) Greenlees, K.J. (2003) Animal drug human food safety toxicology and antimicrobial resistance - the square peg. Int $J$ Toxicol 22: 131-134.

60) McDermott, P.F., Zhao, S., Wagner, D.D., Simjee, S., Walker, R.D., and White, D.G. (2002) The food safety perspective of antibiotic resistance. Anim Biotechnol 13: 7184

61) Jerbi, Mohamed Ali, et al. "Single and combined genotoxic and cytotoxic effects of two xenobiotics widely used in intensive aquaculture." Mutation Research/Genetic Toxicology and Environmental Mutagenesis 724.1 (2011): 2227.

62) Banerjee, S., \& Mitra, S. "Radioactive and Hospital Waste Management: A Review." (2013) Int. J. of latest trends in Engineering and Technology 3-1: 276-282.

63) Forni, C., Patrizi, C., \& Migliore, C. (2006). Floating aquatic macrophytes as a decontamination tool for antimicrobial drugs. In Soil and Water Pollution Monitoring, Protection and Remediation (pp. 467-477). Springer Netherlands.

64) Reddy, K.R., 1983, Fate of nitrogen and phosphorus in wastewater retention reservoir containing aquatic macrophytes, $J$. Environ. Qual. 12: 137-141.

65) Gersberg, R. M., Elkins, B. V., Lyon, S. R., Goldman, C. R., 1986, Role of aquatic plants in wastewater treatment by artificial wetlands, Water Res. 20: 363-368.
66) Gaur, J. P. and Noraho, N., 1995, Adsorption and uptake of cadmium by Azolla pinnata: kinetics of inhibition by cations, Biomed. Environ. Sci. 8: 149-157.

67) Forni, C., Cascone, A., Fiori, M., and Migliore L., 2002, Sulfadimethoxine and Azolla filiculoides Lam.: a model for drug remediation, Water Res. 36: 3398-3403.

68) Forni, C., Tel-Or, E., Bar, E., and Grilli Caiola, M., 1991, Effects of antibiotic treatment on Azolla-Anabaena and Arthrobacter, Plant Soil 137: 151-155.

69) Forni, C., Chen, J. A., Tancioni, L., and Grilli Caiola, M., 2001, Evaluation of the fern Azolla for growth, nitrogen and phosphorus removal from wastewater, Water Res. 35: 1592 1598.

70) Cascone, A., Forni, C. and Migliore, L., 2004, Flumequine uptake and the aquatic duckweed, Lemna minor L., Water Air Soil Pollut. 156: 241-249.

71) Maine, M.A., Duarte M.V., and Suñé, N.L., 2001, Cadmium uptake by floating macrophytes, Water Res. 35: 2629-2634.

72) Rajeshkumar S, Venkatesan C, Sarathi M ,Sarathbabu V, Thomas J, Anver Basha K, Sahul Hameed AS, 2009. Oral delivery of DNA construct using chitosan nanoparticles to protect the shrimp from white spot syndrome virus (WSSV). Fish \& Shellfish Immunology, 26: 429-437.

73) Rather, M. A., Sharma, R., Aklakur, M., Ahmad, S., Kumar, N., Khan, M., \& Ramya, V. L. (2011). Nanotechnology: a novel tool for aquaculture and fisheries development. a prospective mini-review. Fish Aqua, 1-5.

74) Best Management Practices: A Manual for Maryland Aquaculture. Maryland Aquaculture Coordinating Council, 2007.

75) HE, Y. H., ZHANG, H. Y., YUAN, Y. M., \& CHEN, J. Z. (2005). Bioremediation of Water Purifying Microorganism on the Aquaculture Environment [J]. Journal of Jinling Institute of Technology, 3, 026.

76) Schmidt, L. J., Gaikowski, M. P., \& Gingerich, W. H. (2006). Environmental assessment for the use of hydrogen peroxide in aquaculture for treating external fungal and bacterial diseases of cultured fish and fish eggs. USGS Report. 